\title{
Endoscopic findings in the older patients with iron-deficiency anemia
}

Demir eksikliği anemisi olan yaşlı hastalarda endoskopik bulguların değerlendirilmesi

\author{
Ali Şenkaya $\quad$ Ferit Çelik (D) Ömer Özütemiz \\ Ege University Department of Internal Medicine, Division of Gastroenterology, İzmir, Turkey
}

\begin{abstract}
Aim: The presence of iron-deficiency anemia, which is an important indication for endoscopic procedures, in the geriatric population necessitates the exclusion of a possible malignancy in the gastrointestinal system. This study aims to examine endoscopic findings in geriatric patients that underwent esophagogastroduodenoscopy and colonoscopy because of iron-deficiency anemia.

Materials and Methods: Sixty patients aged 65 and over who underwent esophagogastroduodenoscopy and colonoscopy because of iron-deficiency anemia between August 2019 and August 2020 were retrospectively evaluated. Age, sex, geriatric age groups of patients, presence of Helicobacter pylori in gastric biopsy, esophagogastroduodenoscopy findings, colonoscopy findings, presence of internal and / or external hemorrhoids, and duodenal biopsy results were examined.
\end{abstract}

Results: Thirty $(50 \%)$ of 60 patients included in the study were male and the mean age was $72.47 \pm$ 6.07 years. Of these patients, $41(68.4 \%)$ were young-old, $17(28.3 \%)$ were middle-old and $2(3.3 \%)$ were old-old. The most common causes that might explain iron-deficiency anemia in esophagogastroduodenoscopy were atrophic gastritis (21.2\%), Helicobacter pylori-positive gastritis $(20 \%)$, gastric polyp (11.7\%), and gastric cancer (3.3\%), whereas colonoscopy results were found colon polyps in $23.3 \%$ of patients, diverticulum in $15 \%$ and angiodysplasia in $15 \%$, and colon cancer in $8.3 \%$. Internal hemorrhoids were also observed in $44(73.3 \%)$ patients.

Conclusion: In the older population, blood loss from the gastrointestinal system is the most important cause of iron-deficiency anemia and just hemorrhoids cannot explain IDA. While examining the etiology of patients diagnosed with iron-deficiency anemia, performing both esophagogastroduodenoscopy and colonoscopy is an accurate approach to reach the underlying cause and not to miss a possible malignancy.

Keywords: Iron-deficiency anemia, older patient, endoscopy, colonoscopy.

This article was presented as an e-poster at the "International Symposium of World Shaking Pandemic SARSCoV-2 and Elderly Health" held online on 29-30 September 2020.

\section{ÖZ}

Amaç: Endoskopik işlemler için önemli bir endikasyon olan demir eksikliği anemisinin geriatrik popülasyonda varlığı, gastrointestinal sistemde olası bir maligniteyi dışlamayı gerektirmektedir. Bu çalışmada amaç demir eksikliği anemisi nedeni ile özofagogastroduodenoskopi ve kolonoskopi yapılan geriatrik popülasyonda endoskopik bulguların incelenmesidir.

Gereç ve Yöntem: Ağustos 2019-Ağustos 2020 tarihleri arasında demir eksikliği anemisi nedeni ile özofagogastroduodenoskopi ve kolonoskopi yapılan 65 yaş ve üzeri 60 olgu retrospektif olarak değerlendirilmiştir.

Hastaların yaş, cinsiyet, geriatrik yaş grupları, alınan mide biyopsisinde Helicobacter pylori varlığı, özofagoduodenoskopi bulguları, kolonoskopi bulguları, internal ve/veya eksternal hemoroid varlığı, duodenum biyopsisi sonuçları incelenmiştir.

\footnotetext{
Corresponding author: Ferit Çelik

Ege University Department of Internal Medicine, Division of

Gastroenterology, Izmir, Turkey

E-mail: drferitcelik35@yahoo.com.tr
} 
Bulgular: Çalışmaya dahil edilen 60 hastanın 30'u (\%50) erkekti ve yaş ortalaması 72,47 $\pm 6,07$ yıldı. Hastaların 41'i $(\% 68,4)$ genç yaşlı, 17'si $(\% 28,3)$ orta yaşı ve 2'si $(\% 3,3)$ ileri yaşlıydı. Özofagogastroduodenoskopide demir eksikliği anemisini açıklayabilecek en sık bulgular sırasıyla; atrofik gastrit \%21,2, Helicobacter pylori pozitif gastrit \%20, mide polipi \%11,7, mide kanseri \%3,3 iken, kolonoskopik bulgular ise sırasıyla kolon polibi \%23,3 hastada, divertikül \%15, anjiodisplazi \%15, kolon kanseri \%8,3 saptandı. Hastaların $44(\% 73,3)$ 'ünde internal hemoroid izlendi.

Sonuç: Yaşlı popülasyonda gastrointestinal sistemden kan kaybı demir eksikliği anemisinin en önemli nedeni olup, anal bakıda hemoroidlerin görülmesi tek başına demir eksikliği anemisini açıklayamamaktadır. Demir eksikliği anemisi tanısı alan hastaların etiyolojisi araştırıırken hem özofagogastroduodenoskopi hem de kolonoskopi yapılması altta yatan nedene ulaşmak ve olası bir malignitenin atlanmaması açısından doğru bir yaklaşımdır.

Anahtar Sözcükler: Demir eksikliği anemisi, yaşlı hasta, endoskopi, kolonoskopi.

Bu çalışma 29-30 Eylül 2020 tarihlerinde gerçekleştirilen "International Symposium of World Shaking Pandemic SARS-CoV-2 and Elderly Health" çevrimiçi toplantısında elektronik poster olarak sunulmuştur.

\section{INTRODUCTION}

Iron-deficiency anemia (IDA) is the leading cause of anemia in the geriatric population worldwide (1-5). The frequency of etiological causes varies as per age groups in IDA. While the most important cause of IDA is menstrual bleeding in premenopausal women, it is chronic blood losses from the gastrointestinal system (GIS) in postmenopausal women and adult men. The prevalence of IDA in developed countries is $2 \%-$ $5 \%$ in adult men and postmenopausal women, and this constitutes $13 \%$ of patients referred to gastroenterology $(6,7)$. The presence of IDA, an important indication for endoscopic procedures, in the geriatric population necessitates the exclusion of a possible malignancy in GIS (8).

There are not enough studies in Turkey on IDA in the geriatric population. This study aims to examine endoscopic results in a geriatric sample that underwent esophagogastroduodenoscopy and colonoscopy because of IDA.

\section{MATERIAL AND METHODS}

Sixty patients aged 65 and over who underwent esophagogastroduodenoscopy and colonoscopy for IDA between August 2019 and August 2020 were retrospectively evaluated. The data of patients were accessed from the endoscopy database and the hospital electronic patient files, and analyzed. Age, sex, age groups of the older adult patients, presence of Helicobacter pylori $(\mathrm{Hp})$ in gastric biopsy, esophagogastroduodenoscopy and colonoscopy findings, presence of internal and/or external hemorrhoids, and duodenal biopsy results were recorded in the case report form. Endoscopic examinations were performed with GIF-HQ190 esophagogastroduodenoscopy (Olympus, Tokyo, Japan) and CFH-170L-CFQ-150L colonoscopy
(Olympus, Tokyo, Japan) devices by a gastroenterologist or a gastroenterology minor assistant under his supervision, accompanied by an endoscopy nurse.

Those with a known history of lower and/or upper GIS surgery, those with previous GIS malignancy, hematological malignancies, inflammatory bowel disease, and liver cirrhosis were excluded from the study. As defined by the World Health Organization, the older population is divided into three age groups: patients aged 65-74 years are defined as "young-old," 75-84 years as "middle-old," and 85 years and over as "old-old" (9).

Local ethics committee approval was obtained for the study (ethics committee decision date/number: 25.11 .2020 / 20-11.1T/36). The research was conducted as per the principles of the Declaration of Helsinki.

\section{Statistical Analyses}

The compliance of the age variable to normal distribution was examined by visual (histogram) and analytical methods (Kolmogorov-Smirnov test). Age was presented as mean, median, standard deviation, and min-max, whereas categorical data were expressed by descriptive methods such as ratio and percentage. Chisquare test was then used for comparing categorical variables between groups. Values with a $p$ value below 0.05 were considered statistically significant. SPSS Statistics Version 22.0 program was used for all statistical analyses and calculations.

\section{RESULTS}

Thirty $(50 \%)$ of the 60 patients included in the study were male and the mean age was $72.47 \pm$ 6.07 years. Of these patients, 41 (68.4\%) were young-old, $17(28.3 \%)$ were middle-old and 2 
(3.3\%) were old-old; Hp result was positive in 21 (35\%) patients. The most common results in esophagogastroduodenoscopy in patients who underwent esophagogastroduodenoscopy and colonoscopy for IDA were as follows: normal upper GIS findings in 21 (35\%) patients, atrophic gastritis in $13(21.2 \%)$ patients, Hp-positive gastritis in $12(20 \%)$ patients, gastric polyps in 7 $(11.7 \%)$ patients, and gastric cancer in 2 (3.3\%) patients. Colonoscopy results were as follows: normal lower GIS results in 16 (26.7\%) patients, colon polyp in $14(23.3 \%)$ patients, diverticulum in $9(15 \%)$ patients, angiodysplasia in $6(15 \%)$ patients, diverticulum and polyp in $6(10 \%)$ patients and colon cancer in $5(8.3 \%)$ patients. Internal hemorrhoids were observed in 44 (73.3\%) patients. Duodenal biopsy was obtained from $32(53.3 \%)$ of patients for the etiology of IDA; however, all biopsies were reported as normal mucosa (Table-1).
Fifty percent of the patients were using antiaggregant or anticoagulant drugs and the drug types used were acetylsalicylic acid (ASA) $(26.7 \%)$, ASA + clopidogrel $(11.7 \%)$, apixaban $(5 \%)$ in order of frequency. One or more comorbidities were present in $98.4 \%$ of the patients. Three most common comorbidities were, respectively, hypertension, diabetes mellitus and coronary artery disease (Table-2). Iron-deficiency anemia causes in 11 patients $(18.3 \%)$ from upper GIS, in 16 patients $(26.7 \%)$ from lower GIS, in 28 (46.7\%) patients from upper + lower GIS lesions. In 5 patients (8.3\%) could not explain the cause of IDA with both procedures (Figure-1). There was no significant difference between esophagogastroduodenoscopy and colonoscopy findings as per the age group ( $p=0.195$ and 0.130) (Table-3).

Table-1. Demographic, clinical and endoscopic findings of patients.

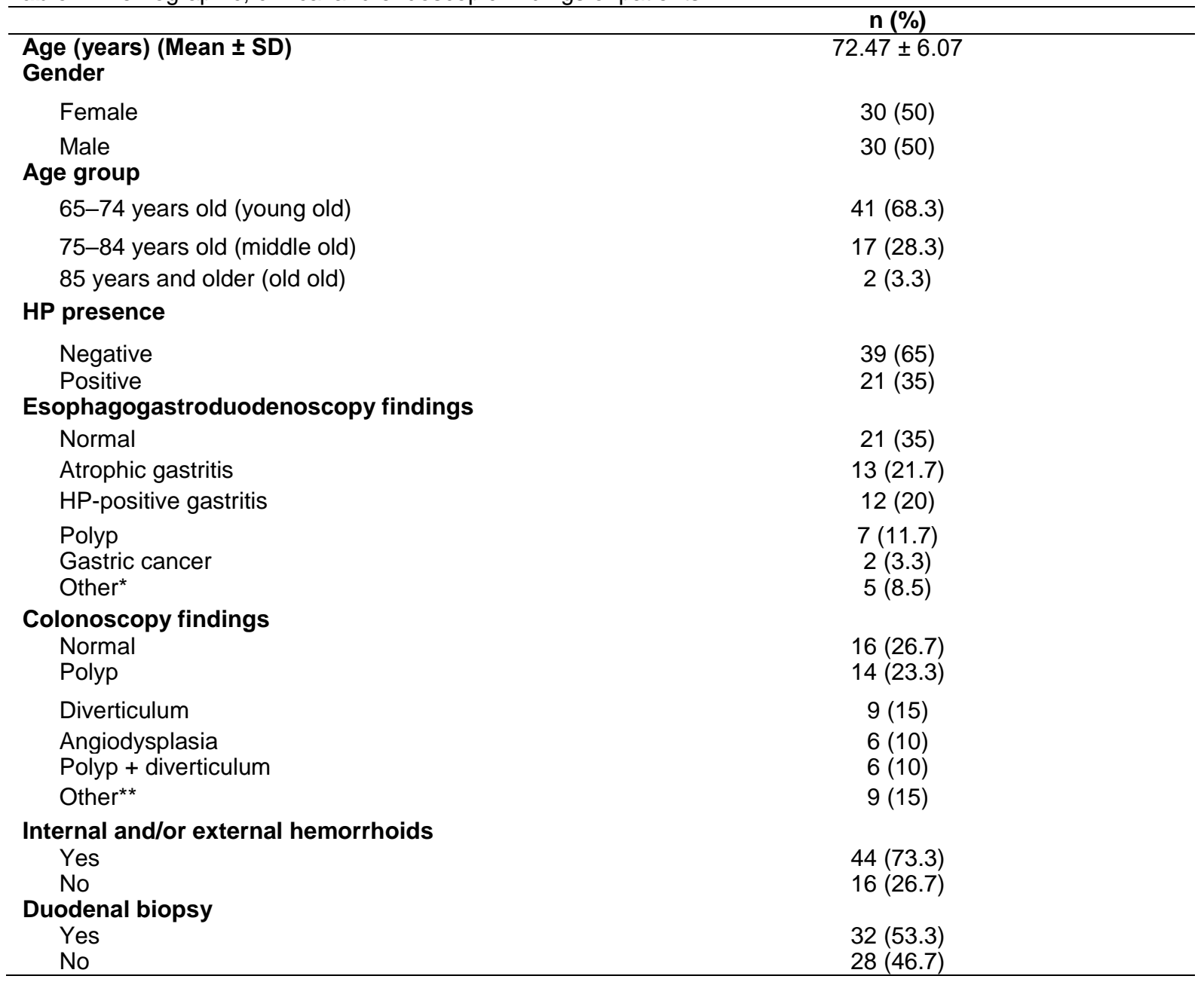

HP, Helicobacter pylori

${ }^{\star}$ Esophageal cancer (1), bulbus ulcer (1), angiodysplasia (1), gastric ulcer (1), HP-positive gastritis + hiatus hernia (1), ${ }^{* *}$ Colon cancer (5), polyp + angiodysplasia (2), terminal ileum ulcer (1), diverticulum + angiodysplasia (1). 
Table-2. Comorbidities and antiaggregant and/or anticoagulant drugs used of the patients.

\begin{tabular}{lc}
\hline Antiaggregant and / or Anticoagulant Drugs & $\mathbf{n}(\%)$ \\
\hline Antiaggregants & \\
ASA & $16(26.7)$ \\
ASA + Clopidogrel & $7(11.7)$ \\
Clopidogrel & $2(3.4)$ \\
Anticoagulants & \\
Apixaban & $3(5)$ \\
Rivaroxaban & $1(1.6)$ \\
Warfarin & $1(1.6)$ \\
No anticoagulant or antiaggregant use & $30(50)$ \\
Number of Comorbidities & \\
No comorbidity & $1(1.6)$ \\
One comorbidity & $10(16.6)$ \\
Two comorbidities & $20(33.4)$ \\
Three or more comorbidities & $29(48.4)$ \\
Three Most Common Comorbidities & \\
HT & $44(73.3)$ \\
DM & $30(50)$ \\
CAD & $17(28.3)$ \\
\hline
\end{tabular}

ASA, Acetylsalicylic acid; HT, Hypertension; DM, Diabetes mellitus; CAD, Coronary artery disease.

Table-3. Comparison of esophagogastroduodenoscopy and colonoscopy findings of patients with iron-deficiency anemia by age groups.

\begin{tabular}{|c|c|c|c|c|}
\hline \multirow[t]{2}{*}{ FINDINGS } & \multicolumn{3}{|c|}{ Age groups } & \multirow[t]{2}{*}{$\mathbf{p}$} \\
\hline & $65-74$ & $75-84$ & $\geq 85$ & \\
\hline Esophagogastroduodenoscopy findings & & & & 0.195 \\
\hline Normal & $15(36.6)$ & $6(35.3)$ & $0(0)$ & \\
\hline Atrophic gastritis & $6(14.6)$ & 7 (41.2) & $0(0)$ & \\
\hline HP-positive gastritis & $10(24.4)$ & $1(5.9)$ & $1(50)$ & \\
\hline Polyps & $4(9.8)$ & $2(11.8)$ & $1(50)$ & \\
\hline Gastric cancer & $1(2.4)$ & $1(5.9)$ & $0(0)$ & \\
\hline Other* & $5(12.2)$ & $0(0)$ & $0(0)$ & \\
\hline Colonoscopy findings & & & & 0.130 \\
\hline Normal & $12(29.3)$ & $4(23.5)$ & $0(0)$ & \\
\hline Polyps & $12(29.3)$ & $2(11.8)$ & $0(0)$ & \\
\hline Diverticulum & 5 (12.2) & $4(23.5)$ & $0(0)$ & \\
\hline Angiodysplasia & $5(12.2)$ & $0(0)$ & $1(50)$ & \\
\hline Polyp + diverticulum & $4(9.8)$ & $2(11.8)$ & $0(0)$ & \\
\hline Other** & $3(7.3)$ & $5(29.4)$ & $1(50)$ & \\
\hline
\end{tabular}

HP, Helicobacter pylori

*Others: Esophageal cancer (1), bulbus ulcer (1), angiodysplasia (1), stomach ulcer (1), and HP-positive gastritis + hiatus hernia (1);

${ }^{\star *}$ Others: Colon cancer (5), polyp + angiodysplasia (2), terminal ileum ulcer (1), and diverticulum + angiodysplasia (1) 


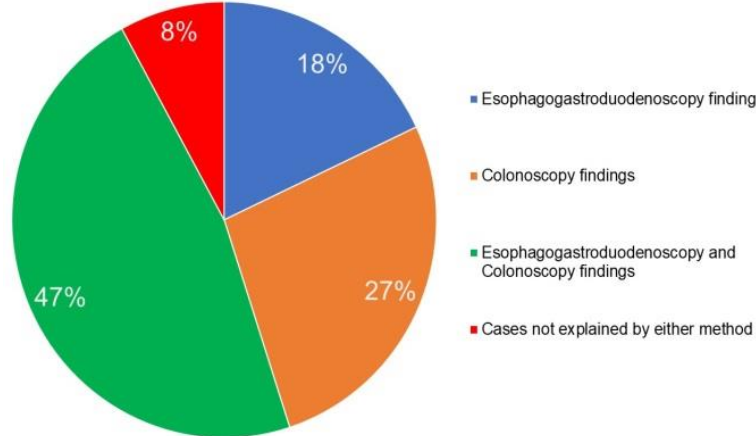

Figure-1. Endoscopic diagnostic methods in determining the etiology of iron-deficiency anemia.

\section{DISCUSSION}

IDA is one of the major health problems in the geriatric population, and the Third National Health and Nutrition Examination Survey (NHANES III, 1988-1994) demonstrated that the prevalence of IDA in the older adults is $\sim 10.6 \%$ (2). Note that $63 \%-86 \%$ of IDA cases in the geriatric population are attributed to bleeding gastrointestinal lesions (10-14).

Although there are specific symptoms in GISrelated anemia, it is recommended that upper and lower gastrointestinal endoscopic examinations be performed concurrently. Because different etiological reasons may be together (12). While the cause of IDA cannot be determined in $30 \%-50 \%$ of those undergoing only gastroscopy in etiological evaluation, this rate decreases to $15 \%$ when gastroscopy and colonoscopy are performed together (15-17). Note that $20 \%$ of older patients have a negative upper and lower endoscopy, and two-thirds of these have a lesion in the small intestine (18). After negative standard dual endoscopic evaluations, it is important to examine the small intestine in all patients with unexplained IDA (19). In a study conducted by Çoban et al. on the etiology of IDA in the geriatric population in Turkey, although both upper and lower GIS endoscopy was performed, no etiological cause was reported in GIS scanning in $15.6 \%$ of patients (20). In our study, the results that could explain the IDA of the patients were reported only in esophagogastroduodenoscopy in $18.3 \%$ patients, only in colonoscopy in $26.7 \%$, in both esophagogastroduodenoscopy and colonoscopy in $46.7 \%$ patients, and no results were detected in either endoscopic method in $8.3 \%$ patients. Compared to the literature, the ratio of patients in this study where either method failed to provide any results is lower. This is possibly attributed to an experienced tertiary center; during the procedure, a team comprising a specialist physician, a minor assistant and an experienced nurse performed the procedure, which minimized possible overlooked lesions.

In the literature that in postmenopausal women and men $>50$ years of age, $2 \%-15 \%$ of patients were diagnosed with colorectal cancer and $2 \%-$ $6 \%$ were diagnosed with upper gastrointestinal system cancer in investigations because of IDA (14, 21-23). In studies conducted in Turkey, a diagnosis of adenocarcinoma was made in $0.9 \%-7.7 \%$ of patients who underwent upper gastrointestinal endoscopy and in $4.7 \%-9.5 \%$ of patients who underwent lower gastrointestinal endoscopy for IDA $(24,25)$. In another study in Turkey in which endoscopy and colonoscopy was performed because of IDA in the geriatric population, upper GIS cancer was reported in $4.4 \%-7.3 \%$ of patients and colon cancer was reported in $6 \%-8.3 \%$ of them $(18,26)$. In this study, gastric cancer was reported in $3.3 \%$ and colon cancer in $8.3 \%$ of the cases. As per these results, the incidence of gastric cancer was less compared to other studies conducted in the geriatric population; however, the colon cancer incidence was similar to the rates reported in the literature.

In a study examining the cause of anemia because of chronic blood loss or malabsorption as per different age groups, bleeding lesions were reported to be $29 \%$ in adult patients (50-64 years) and $45.5 \%$ more in older patients $(65-74$ years). Iron-deficiency because of malabsorption (Hp-positive pangastritis, atrophic gastritis and celiac disease) was reported in $80.6 \%$ of adults and $56.2 \%$ of the older patients (27). Studies demonstrated that the prevalence of celiac disease in patients with IDA is $3 \%-15 \%$, the prevalence of atrophic gastritis is $20-27 \%$, and the rate of $\mathrm{Hp}$-positive gastritis is $25 \%-44 \%$ (26, $28,29)$. In this study, the rate of atrophic gastritis was $21.7 \%$ and $\mathrm{Hp}$-positive gastritis was $20 \%$, which is consistent with the literature. Furthermore, in this study, the rate of atrophic gastritis and $\mathrm{Hp}$-positive gastritis was reported to be higher in the 75-84 age group compared to the 65-74 age group; however, statistical significance was not observed. Duodenal biopsy was considered for celiac disease in $53.3 \%$ of our cases; however, no disease was reported in any of the patients. These results support the 
necessity of biopsy in terms of $\mathrm{Hp}$-associated gastritis and atrophic gastritis, although there is no obvious lesion in the upper GIS examination in patients with IDA.

Hemorrhoids are one of the results obtained in examining the lower gastrointestinal system. In the literature, hemorrhoids have been reported in $39 \%$ of colonoscopies performed for routine colorectal cancer screening (30). In studies conducted in Turkey, hemorrhoids were reported with a rate of $13.6 \%-33.4 \%(25,31,32)$. In this study, $73.3 \%$ of patients had internal and/or external hemorrhoids. As per the literature, there is no clear explanation for this high rate; however, attributing anemia to hemorrhoids in patients with a history of hemorrhoids may lead to overlooking the presence of other underlying etiologies.

There are certain limitations of this study. These include the retrospective design, limited number of patients, lack of occult blood data in the stool, lack of information on the drugs regularly used by the patients, lack of information on patient symptoms, and lack of small intestinal examination in the patients with normal lower and upper endoscopic examinations.

\section{CONCLUSION}

In the older population, blood loss from GIS is the most important cause of IDA; hemorrhoids seen in anal examination alone cannot explain IDA. While examining the etiology of patients diagnosed with IDA, performing both esophagogastroduodenoscopy and colonoscopy is an accurate approach for illuminating the underlying cause and not missing a possible malignancy.

Conflict of interest: All authors acknowledge that there is no conflict of interest.

No financial support has been received.

\section{References}

1. Kassebaum NJ, Jasrasaria R, Naghavi M, et al. A systematic analysis of global anemia burden from 1990 to 2010. Blood 2014; 123: 615-24.

2. National Center for Health Statistics, The Third National Health and Nutrition Survey (NHANES III, 19881994). Reference Manuals and Reports. 1996.

3. Smith DL. Anemia in the Elderly. Am Fam Physician 2000; 62: 1565-72.

4. Joosten E, Pelemans W, Hiele M, et al. Prevalence and causes of anemia in a geriatric hospitalized population. Gerontology 1992; 38: 111-7.

5. Milman N. Anemia--still a major health problem in many parts of the world! Ann Hematol 2011; 90: 369-77.

6. Gunter EW, Lewis BG, Koncikowski SM. Laboratory procedures used for the Third National Health and Nutrition Examination Survey (NHANES III), 1988-1994. US Dep Heal Hum Serv Public Heal Serv Centers Dis Control Prev Natl Cent Environ Heal Atlanta, GA, Natl Cent Heal Stat Hyattsville, MD. 1996.

7. Bull-Henry K, Al-Kawas FH. Evaluation of occult gastrointestinal bleeding. Am Fam Physician 2013; 87: 430-6.

8. Liu K, Kaffes AJ. Iron deficiency anaemia: a review of diagnosis, investigation and management. Eur $\mathrm{J}$ Gastroenterol Hepatol 2012; 24: 109-16.

9. WHO (1972) Psychogeriatric, report of a WHO Scientific Group, Technical Reports Series 507, Geneva. Cited in Davise AM. Epidemiology 185; 14 (1): 9-21.

10. Pang WW, Schrier SL. Anemia in the elderly. Curr Opin Hematol 2012; 19: 133-40.

11. Capurso G, Baccini F, Osborn J, et al. Can patient characteristics predict the outcome of endoscopic evaluation of iron deficiency anemia: a multiple logistic regression analysis. Gastrointest Endosc 2004; 59: 766-71.

12. Annibale B, Capurso G, Chistolini A, et al. Gastrointestinal causes of refractory iron deficiency anemia in patients without gastrointestinal symptoms. Am J Med 2001; 111: 439-45.

13. Rockey DC. Occult gastrointestinal bleeding. Gastroenterol Clin N Am 2005; 34: 699-718.

14. Stephens MR, Hopper AN, White SR, et al. Colonoscopy first for iron-deficiency anemia: a number needed to investigate approach. Q J Med 2006; 99: 389-95.

15. Zuckerman G, Benitez J. A prospective study of bidirectional endoscopy (colonoscopy and upper endoscopy) in the evaluation of patients with occult gastrointestinal bleeding. Am J Gastroenterol 1992; 87: 62-6.

16. Gordon SR, Smith RE, Power GC. The role of endoscopy in the evaluation of iron deficiency anemia in patients over the age of 50. Am J Gastroenterol 1994; 89: 1963-7.

17. Bull-Henry K, Al-Kawas FH. Evaluation of occult gastrointestinal bleeding. Am Fam Physician 2013; 87: 430-6. 
18. American Gastroenterological Association medical position statement: evaluation and management of occult and obscure gastrointestinal bleeding. Gastroenterology 2000; 118: 197-201.

19. Fisher L, Lee Krinsky M, et al. The role of endoscopy in the management of obscure Gl bleeding. Gastrointest Endosc 2010; 72: 471-9.

20. Coban E, Timuragaoglu A, Meriç M. Iron deficiency anemia in the elderly: prevalence and endoscopic evaluation of the gastrointestinal tract in outpatients. Acta Haematol 2003; 110 (1): 25-8.

21. Luman W, Ng KL. Audit of investigations in patients with iron deficiency anaemia. Singapore Med J 2003; 44: 504-10.

22. Lindsay JO, Robinson SD, Jackson JE, et al. The investigation of iron deficiency anemia-a hospital based audit. Hepatogastroenterology 1999; 46: 2887-90.

23. Majid S, Salih M, Wasaya R, et al. Predictors of gastrointestinal lesions on endoscopy in iron deficiency anemia without gastrointestinal symptoms. BMC Gastroenterol 2008; 8: 52.

24. Ünal ÜH, Fidan C, Korkmaz M, Selçuk H. Demir eksikliği olan hastalarda gastrointestinal sistem endoskopi bulguları. Akademik Gastroenteroloji Dergisi 2012; 3: 113-6

25. Yaylacı S, Genç AB, Tamer A, Cinemre H, Uslan Mi. Demir eksikliği anemisi nedeniyle takipli hastalarda endoskopi sonuçları. Kocaeli Tıp Dergisi 2014; 2: 16-9.

26. Yüksel M, Saka B, Vatansever S. Yaşlılarda demir eksikliği anemisi etyolojisinin ve sıkığının saptanması İ̧ Hastalıkları Dergisi 2012; 19: 87-97.

27. Vannella L, Aloe Spiriti MA, Di Giulio E, et al. Upper and lower gastrointestinal causes of iron deficiency anemia in elderly compared with adult outpatients. Minerva Gastroenterol Dietol 2010; 56: 397-404.

28. Zhu A, Kaneshiro M, Kaunitz JD. Evaluation and treatment of iron deficiency anemia: a gastroenterological perspective. Dig Dis Sci 2010; 55: 548-59.

29. Bermejo F, García-López S. A guide to diagnosis of iron deficiency and iron deficiency anemia in digestive diseases. World J Gastroenterol 2009; 15: 4638-43.

30. Riss S, Weiser FA, Schwameis K, et al. The prevalence of hemorrhoids in adults. Int J Colorectal Dis 2012; $27(2): 215-20$.

31. Tamer A, Korkut E, Korkmaz U, Akcan Y. Alt gastrointestinal endoskopi sonuclarımız: Duzce bolgesi. The Medical Journal of Kocatepe 2005; 6: 29-31.

32. Okuturlar Y, Soylu A, İnan Y, ve ark. Demir eksikliği anemisi olan hastalarda alt ve üst gastrointestinal endoskopik inceleme sonuçları. Endoskopi Gastrointestinal 2014; 22 (2): 33-7. 